\title{
CAPITALISMO, CRISES, DEMOCRACIA E A CONSTITUIÇÃO BRASILEIRA
}

\author{
CAPITALISM, CRISIS, DEMOCRACY AND BRAZILIAN CONSTITUTION
}

Jefferson Aparecido Dias

\begin{abstract}
Doutor em Direitos Humanos e Desenvolvimento pela Universidade Pablo de Olavide de Sevilha (Espanha), Procurador da República em Marília, Procurador Regional dos Direitos do Cidadão Substituto do Estado de São Paulo e Professor do Mestrado em Direito da Universidade de Marília (UNIMAR). E-mail: jeff.bojador@gmail.com

Pedro Antonio de Oliveira Machado

Mestrando em Direito da Universidade de Marília (UNIMAR), Procurador da República em Bauru e Procurador Regional dos Direitos do Cidadão do Estado de São Paulo.

E-mail: pedromachado@mpf.mp.br
\end{abstract}

Recebido em: 18/10/2016

Aprovado em: 08/11/2016

Doi: $10.5585 / \mathrm{rdb} . v 15 i 6.511$

RESUMO: A supremacia do capitalismo, o seu espírito, os seus deslocamentos, as crises geradas a partir dele e por ele serão abordadas, ainda que brevemente, sob os aspectos, históricos, filosóficos, jurídicos, com um olhar também atento ao enfraquecimento do poder dos Estados e dos organismos internacionais dos quais fazem parte os Estados, que estão perdendo a capacidade de gerar bem-estar social, o que coloca em risco a democracia e o compromisso global de busca de justiça social, circunstâncias às quais o Brasil, num mundo globalizado, também está exposto, o que representa um teste para a força normativa de nossa Constituição e o alcance da reação que se verificou nas manifestações e protestos nas ruas e praças do país.

Palavras-chave: Estado Democrático. Sistema capitalista. Bem-estar social.

\begin{abstract}
The capitalism supremacy, its sense, its displacements, crisis generated from it and by it, will be addressed, albeit briefly, under the historical, philosophy and legal aspects, with a close look also to the weakening of political power and international organisations, that are losing the ability to generate social welfare, which jeopardise the democracy and the global commitment to seeking social justice, circumstances in relation to which Brazil, in a globalised world, is also exposed, representing a teste for the normative force of the Constitution and the reach of reaction to the protests and demonstrations which occurred in the contry's streets and squares.
\end{abstract}

Key words: Democratic State. Capitalist System. Welfare.

SUMÁRIO: Introdução; 1. Governando com e apesar do capitalismo; 2. Compreendendo o espírito do capitalismo; 3. O capitalismo e seus deslocamentos (welfare state) reagindo à ideologia do socialismo; 4. As mais recentes crises gerados pelo capitalismo e também a partir dele; 5. Capitalismos, suas crises e a Constituição Brasileira; Conclusão; Bibliografia 


\section{INTRODUÇÃO}

O capitalismo, sistema praticamente hegemônico no mundo atual, após o fim da ilusão do comunismo, a queda do Muro de Berlim e o fim da Guerra Fria, precisa ser melhor compreendido, quanto à sua força para seduzir e engajar as pessoas, assimilar as críticas, se deslocar e manter-se sempre forte, vendendo-se como a única opção capaz de trazer liberdade e bem comum.

Para tanto, a tentativa será de identificar e esmiuçar o que alguns estudiosos do tema denominam de espírito do capitalismo e, também como ele agiu e continua agindo sobre as pessoas, mantendo a sua lógica de acumulação ilimitada e convencendo que a felicidade está diretamente ligada à obtenção de riqueza material, sem contudo deixar que a insaciabilidade que ele estimula não seja a ruína do próprio sistema.

O acompanhamento dos principais fatos históricos e culturais, das ideologias econômicas que tiveram maior influência e das sucessivas crises que circundaram o capitalismo será tarefa cuja tentativa será empreendida no sentido de melhor entender a lógica autofágica e perigosa do sistema capitalista de tratar a terra, a moeda e a força de trabalho como mercadoria e não como condições de produção.

A constante luta capital e trabalho representados, por exemplo, nos dias atuais pelas greves que assolam a França numa reação contra reformas trabalhistas de cunho liberalizante que se pretende implementar naquele país, com redução de direitos e de garantias para os trabalhadores, assim como o que já representou essa luta historicamente, através dos sindicatos e da constituição da Organização Internacional do Trabalho (OIT), da instituição dos Estados de bem-estar social (welfare state), também merecerá detida reflexão.

De outra banda não se deixará de fora da empreitada, cujo esforço será aqui empreendido, a abordagem da reação do capitalismo através do neoliberalismo e de seus idealizadores, que solaparam, lenta e gradualmente boa parte das conquistas do welfare state.

Por fim se dedicará espaço para refletir o Brasil nesse contexto de crise, consideradas as promessas estabelecidas na Constituição cidadão de 1988, o contexto no qual foi ela gestada e o que devemos esperar, considerado o roteiro nela traçado, de busca da justiça social e do bemestar de todos, em contrapartida aos interesses do mercado capitalista que tende a tudo capturar, inclusive com força para colocar em cheque o poder estatal e a própria democracia.

\section{GOVERNANDO COM E APESAR DO CAPITALISMO}

A arte de governar está em dosar a intervenção do Estado para que o egoísmo que é o combustível do capitalismo, a sua mola propulsora, seja mantido sob certo controle, e isto, digase de passagem, para não prejudicar a própria economia e o mercado e, para além, visando tornar possível a implementação do que declarado internacionalmente, já em 1919, como parte do Tratado de Versalhes, que pôs fim à Primeira Guerra Mundial, quando então se fez inserir no preâmbulo da Constituição da Organização Internacional do Trabalho (OIT) que só é possível uma paz universal e duradoura com base na justiça social e no enfrentamento do problema de que existem condições de trabalho que implicam, para grande parte das pessoas, a injustiça, a miséria e as privações, o que gera um descontentamento tal que a paz e a harmonia universais são postas em risco. Aliás o texto foi ratificado, no final da Segunda Guerra Mundial, em meados da década de 1940, pela OIT, sendo inclusive incorporado ao direito pátrio pelo Decreto $\mathrm{n}^{\mathrm{o}} 25.696$, de 20 de outubro de 1948.

Esse enfrentamento, a ser levado a efeito pelos governantes, em relação ao sistema capitalista, com o seu predador formato de produção, consumo e relações sociais, e as consequências daí advindas, representadas nos prejuízos sobre o bem-estar geral (v.g. respeito aos

Revista de Direito Brasileira | São Paulo, SP | v. 15 | n. 6 | p. 94- 115 | set./dez. 2016 
consumidores e ao meio ambiente, mas não só), tem se mostrado uma missão difícil, exercida insuficientemente, no mais das vezes capturada pelos próprios interesses egoísticos do mercado, talvez impossível ou quem sabe utópica (aliás, por significativa e mais recente, cite-se a catástrofe, de grandes e graves proporções, do rompimento das barragens da mineradora Samarco, em Mariana/ $\mathrm{MG}^{1}$ ).

No ponto vale aqui destacar a visão pessimista do filósofo, jornalista, escritor e professor francês Régis Debray, doutorado na Escola Normal Superior de Paris, hoje com 75 anos, mas que quando jovem chegou a se envolver com a guerrilha armada, ao lado de Che Guevara, na América Latina:

O poder político consiste em administrar as ilusões. Quando um político se dirige à esquerda, ele promete justiça e igualdade. Quando se dirige à direita, promete eficiência, lucro e sucesso. Normalmente, as promessas não são cumpridas.

$[\ldots]$

O que acaba de acontecer na Grécia revelou algo terrível: pode haver democracia sem povo. Vota-se, mas as decisões finais ocorrem em outro nível, mais alto e não nacional, de uma burocracia financeira europeia. Os referendos perderam toda a importância. O povo tornou-se impotente. Já não tem ascendência sobre seu destino. A elite tecnocrata no poder não está nem aí para o voto popular, porque decide o que mais lhe convém.

$[\ldots]$

Vivemos um capitalismo degenerado, que idolatra o sistema financeiro e não busca produzir o bemestar interior ou coletivo, mas sim o lucro e a mais-valia. Um mundo submisso à lei da rentabilidade do dinheiro. É perverso. A política sucumbiu à economia, que não é uma ciência, mas uma técnica, falha como tantas. Na França, os jovens brilhantes não entram mais na política, vão para as finanças, para os bancos e o mercado. A carreira política é hoje para os imbecis. Ou para quem quer saciar uma vaidade, o desejo de ser amado. É mais um arrivismo social que uma ambição política de verdade. Não é um sentimento nobre. $^{2}$

Mas é preciso compreender e tentar lidar com esse sistema capitalista, praticamente hegemônico no mundo atual, após o fim da ilusão do comunismo, com o advento da Glasnost (abertura e reestruturação política, para criação de um ambiente democrático, de maior liberdade de expressão e manifestação) e da Perestroika ("modernização" e diminuição da burocracia na economia, abertura econômica etc.) na URSS, além da queda do Muro de Berlim (barreira física e fortemente vigiada que separava a parte oriental/comunista da ocidental/capitalista, da cidade) e, ainda, o fim da Guerra Fria (período histórico de contendas e conflitos de cunho estratégico entre os Estados Unidos e a União Soviética, e seus respectivos aliados).

1 PEREIRA, Jeferson Botelho. Desastre de Mariana/MG e responsabilidade penal da pessoa jurídica. Revista Jus Navigandi, Teresina, ano 20, n. 4518, 14 nov. 2015. Disponível em: 〈https://jus.com.br/artigos/44355>. Acesso em: 28 jun. 2016. /// Veja também: A TRAGÉDIA de Mariana. Estadão. Opinião. Editorial. 11.11.2015. Disponível em: <http://opiniao.estadao.com.br/noticias/geral,a-tragedia-de-mariana,10000001681> Acesso em 29 jun. 2016

2 AQUINO, Ruth. Régis Debray: “A esquerda está sem voz": O filósofo francês, companheiro de guerrilha de Che Guevara, elogia o "revoltado" papa Francisco e diz que o islamismo é a única oposição séria ao capitalismo. 24.08.2015. Revista Época. Edição On line. Disponível em: < http://epoca.globo.com/ideias/noticia/2015/08/regisdebray-esquerda-esta-sem-voz.html> - Acesso em 28 jun. 2016. 


\section{COMPREENDENDO O ESPÍRITO DO CAPITALISMO}

Nessa missão de compreender o capitalismo, Luc Boltanski e Éve Chiapello ${ }^{3}$ apontam para uma pista, ao apregoar que como ele não dispõe do poder das armas (já que o monopólio legítimo da violência está nas mãos do Estado), sua característica de exigência de acumulação ilimitada (insaciável) do capital se dá através de meios formalmente pacíficos (conquanto o seu motor seja o egoísmo), o que demanda sejam apresentadas razões aceitáveis e convincentes para o engajamento das pessoas, já que elas não deixam de existir fora do trabalho, pois vivenciam outras dimensões (familiar, de amizades, religiosas, cultural, política etc.). Assim, para tais autores, a justificação do capitalismo estaria no que denominam eles de um espírito do capitalismo, consubstanciado numa ideologia que é vendida com sucesso (e convence), estimulando de forma controlada a insaciabilidade das pessoas, apostando na inclinação humana para acumular ganhos, poder, invenções e experiências diferentes e, ao mesmo tempo, estabelecendo exigências morais que a limitam (instituição da proteção ao direito de propriedade, por exemplo), impondo sobre ela (insaciabilidade), por outro lado, injunções de bem comum.

Sob tal perspectiva, interessante ainda meditar sobre o que observa, a certa altura de sua obra "A Democracia na América", Alexis de Tocqueville:

Se considero agora o homem à parte, descubro que as crenças dogmáticas lhe são tão indispensáveis para viver sozinho como para agir em comum com seus semelhantes. Se o homem fosse forçado a provar a si próprio todas as verdades de que se vale todos os dias, não acabaria nunca; esgotar-se-ia em demonstrações preliminares sem avançar; como não tem tempo, por causa do curto período da vida, nem faculdade para assim agir, por causa dos limites de seu espírito, é reduzido a dar por certa uma porção de fatos e de opiniões que não teve nem o vagar nem a possibilidade de examinar e verificar por si mesmo, mas que outros encontraram ou que a multidão adota. É sobre esse primeiro fundamento que ele próprio ergue o edifício de seus pensamentos pessoais. Não é sua vontade que o leva a proceder dessa maneira, a lei inflexível da sua condição é que o obriga a tanto. ${ }^{4}$

Outrossim, à pista dos autores franceses (Boltanski e Chiapello), vale adicionar o que Max Weber ${ }^{5}$ identificou, a partir das ideias de João Calvino (calvinismo) e de Martinho Lutero (este um dos protogonistas da reforma protestante, de um modelo de religião que se opôs aos dogmas da igreja católica, notadamente a venda de indulgências), como reação que acabou também por contribuir para um espírito do capitalismo, através da desconstrução da ideologia de que a obtenção de lucro estaria ligada ao pecado, consideradas as suas vigas mestras (da reforma protestante), defendendo-se então que as riquezas devem ser tidas como sinal da bênção de Deus; de que os cristãos devem evitar os prazeres mundanos, conquanto apontando para a ideia de que a única fonte de prazer que Deus dá ao homem é o trabalho, a ser executado de forma racional e metódica; e, por fim, que o lucro deve ser visto como um prêmio recebido por contentar Deus através do trabalho.

Sob tal prisma é sintomático notar que nos Estados Unidos da América, que sempre cultivou o modelo capitalista, o protestantismo teve muita força (e ainda hoje tem, conquanto em

3 BOLTANSKI, Luc; CHIAPELLO, Ève. O novo espírito do capitalismo. São Paulo: Martins Fontes, 2009, p. 481 484. Tradução: Ivone C. Benedetti

4 TOCQUEVILLE, Alexis de. A Democracia na América: Livro II Sentimentos e Opiniões. São Paulo: Martins Fontes, 2004, p. 9-10. Tradução: Eduardo Brandão

5 WEBER, Max. A ética protestante e o espírito do capitalismo. $2^{a}$ Edição Revista. Editora: Pioneira, p. 8

Revista de Direito Brasileira | São Paulo, SP | v. 15 | n. 6 | p. 94- 115 | set./dez. 2016 
menor grau), conforme demonstra o teólogo, historiador e pastor Alderi Souza de Matos ${ }^{6}$, em artigo que está hospedado no site do Instituto Presbiteriano Mackeinzie.

\section{O CAPITALISMO E SEUS DESLOCAMENTOS (WELFARE STATE) REAGINDO À IDEOLOGIA DO SOCIALISMO}

Por outo lado, é curioso obsevar, também, conforme registra E. K. Hunt ${ }^{7}$, que Adam Smith (que pode ser considerado um dos pais do capitalismo), acreditava que a natureza tinha, em toda parte, criado nas pessoas a ilusão de que a felicidade pessoal era fruto, principalmente, da riqueza material. Conquanto ele mesmo não acreditasse nessa ilusão, teria se impressionado com os efeitos econômicos e sociais desse desejo de ganhos pessoais e as consequências (positivas na sua visão) desse movimento contínuo da operosidade da humanidade, que incitou os homens a cultivar o solo, a construir casas, a fundar cidades e comunidades e a inventar e fazer progredir todas as ciências e artes que enobrecem e embelezam a própria vida dos homens.

Esmiuçando mais tal raciocínio, continua E. K. Hunt ${ }^{8}$ a explicar que Smith, quando descreve o fluxo de capital para a indústria interna num "sistema de liberdade natural", formula a proposição mais famosa de sua tese, segundo a qual em um mercado livre os atos egoístas dos indivíduos (na incessante busca da riqueza pessoal) são dirigidos, como que por uma "mão invisível", gerando, independente da vontade desses mesmos indivíduos, a maximização do bemestar econômico, motivo pelo qual concluiu ele (Smith) que as intervenções, as regulamentações, as concessões de monopólio e os subsídios especiais do governo tendiam a alocar mal o capital, diminuindo sua contribuição para o bem-estar econômico, pois restringiam os mercados, reduziam a taxa de acumulação de capital e a extensão da divisão do trabalho, afetando negativamente o nível de produção social. Em razão disso a preservação de um mercado livre, essencialmente concorrencial, laissez-faire, era socialmente benéfico e harmonioso, daí porque as funções do governo deveriam ser limitadas, sem interferir na forma como seria empregado o capital.

Todavia, essa visão, na prática, não se mostrou coesa e nem com essa propalada coerência, quando, por exemplo, o desemprego na Inglaterra se mostrava persistente desde o início de 1920, se alastrando por outros países da Europa, ao tempo em que, do outro lado do Atlântico, nos Estados Unidos, a quebra (crack) da bolsa de valores de Nova York, no final dessa mesma década de 20, gerava um desemprego alarmante e impunha uma grande depressão econômica ao país americano, tido como o pior e o mais longo período de recessão econômica do século XX, gerando graves repercussões econômicas (negativas) em outras nações, com quedas drásticas em seus produtos internos brutos.

Diante desse quadro a reação se deu, nas décadas que se seguiram, em apertada síntese, com a adoção do chamado modelo keynesiano, desenvolvido pelo economista britânico John Maynard Keynes em sua famosa obra "Teoria geral do emprego, do juro e da moeda" (General theory of employment, interest and money), conforme destaca Carlos Roberto Vieira Araújo", com a não aceitação da teoria da "mão invisível" do mercado, e defendendo uma forte intervenção do Estado na economia, por meio de políticas monetárias e fiscais, influenciando as taxas de juros, adotando expedientes relativos ao uso da tributação e dos gastos governamentais,

6 MATOS, Alderi Souza de.O protestantismo norte-americano: séculos 17 a 19. Disponível em: < http://www.mackenzie.br/7111.html> - Acesso em 28 jun. 2016

7 HUNT, E. K. História do Pensamento Econômico. Tradução de José Ricardo Brandão Azevedo e Maria José Cyhlar Monteiro. Rio de Janeiro: Campus, 2005, p. 43

8 HUNT, E. K. História do Pensamento Econômico. Tradução de José Ricardo Brandão Azevedo e Maria José Cyhlar Monteiro. Rio de Janeiro: Campus, 2005, p. 56 e 57

9 ARAÚJO, Carlos Roberto Vieira. História do pensamento econômico: uma abordagem introdutória. São Paulo: Editora Atlas, 1995, p. 132-133

Revista de Direito Brasileira | São Paulo, SP | v. 15 | n. 6 | p. 94 - 115 | set./dez. 2016 
visando aumentar o nível de emprego, da renda e consequentemente de demanda, para alavancar o ambiente econômico, ainda que, por um determinado tempo, isso possa gerar déficits orçamentários nos governos. Nos Estados Unidos isso se traduziu na política econômica conhecida por New Deal, entre 1933 e 1937, adotada no governo do Presidente Franklin Delano Roosevelt.

Para além, essa crise do capitalismo liberal ou do liberalismo econômico, cumulado ao embate ideológico da Guerra Fria, gerou ambiente propício ao surgimento dos Estados de bemestar social. Tome-se o campo das relações de trabalho subordinado, da luta capital trabalho, seara na qual noticía Enzo Roppo ${ }^{10}$, a instituição penosa, lenta e gradual, mas consistente e efetiva, do contrato coletivo de trabalho, com a sua força normativa, protegendo coletivamente os trabalhadores, assumindo importância crescente com o desenvolvimento e influência do papel do movimento sindical, estabelecendo o equilíbrio da contratualidade nas relações entre empresários e trabalhadores, contando nesse campo também com a intervenção autoritária externa do poder público, geralmente através do legislador, atuando mediante prescrições normativas formais (direitos trabalhistas), visando trazer uma liberdade substancial, em relações nas quais os contratantes não estão em pé de igualdade.

Num sentido mais amplo José Luís Fiori ${ }^{11}$, sem se comprometer com as várias teses que explicariam o surgimento do(s) Estado(s) de bem-estar social, para ele todas inconclusivas, descreve algumas pistas, colhidas da literatura que estuda o tema, dentre as quais, a exigência da industrialização ou da acumulação do capital, ou da modernização e urbanização, ainda como resultado do avanço dos direitos dos cidadãos e da democracia, talvez como produto da mobilização sindical e da luta política de classes, quem sabe como obra de elites divididas ou fortemente pressionadas ou, ainda, quiçá como resultado das pressões e da força política circunstancial da classe trabalhadora.

Revelador da preocupação ideológica com o avanço do socialismo, foi a publicação em 1953 do livro "Social Responsibilities of the Businessman", traduzido no Brasil por Octávio Alves Velho, sob o título "Responsabilidades Sociais do Homem de Negócios", cujo autor, Howard R. Bowen (professor de economia do "Williams College") foi contratado no âmbito de um projeto mais amplo, iniciado em 1949, pelo Conselho Federal das Igrejas de Cristo na América, sobre ética e vida econômica cristã, recebendo subvenção da Fundação Rockefeller (que não teria, segundo o prefácio do livro, exercido qualquer influência intelectual nos estudos). Nessa obra ${ }^{12}$ (relembre-se, publicada em 1953, em plena Guerra Fria), a certa certa altura alerta o autor que se está entrando em uma era na qual os negócios privados serão julgados exclusivamente em função de sua contribuição concreta para o bem-estar coletivo, de modo que a aceitação de obrigações para com os trabalhadores, consumidores e público em geral, é um requisito para a sobrevivência do sistema de livre empresa (a livre iniciativa, frise-se). Devendose assim tomar não só as conveniências dos acionistas como único alvo dos negócios, tornandose mandatória para a administração das grandes empresas, a solicitude com objetivos sociais mais vastos.

Essa cautela com a possibilidade do avanço do socialismo, em razão de todas as circunstâncias e consequências das crises econômicas já mencionadas, propiciaram a readequação (deslocamento) do sistema capitalista, que se rendeu, à época, à instituição de modelos de Estado de bem-estar social, notadamente na Europa e na América do Norte, cuja proteção social em

10 ROPPO, Enzo. Transformações do contrato na sociedade contemporânea "declínio" ou "relançamento" do instrumento contratual?. In: ROPPO, Enzo. O Contrato. Coimbra: Almedina, 1988. Cap. V. p. 325-327

11 FIORI, José Luís. Estado de bem-estar social: padrões e crises. Physis, Rio de Janeiro, v. 7, n. 2, p. 129-147, Dez. 1997. Disponível em: <http://www.scielo.br/scielo.php?script=sci_arttext\&pid=S010373311997000200008\&lng=en\&nrm=iso>. Acesso em 28 jun. 2016. http://dx.doi.org/10.1590/S010373311997000200008.

12 BOWEN, Howard R.. Responsabilidades Sociais do Homem de Negócios. Tradução de Octávio Alves Velho. Rio de Janeiro: Civilização Brasileira S/A, 1957, p. 3-5, 66-67.

Revista de Direito Brasileira | São Paulo, SP | v. 15 | n. 6 | p. 94- 115 | set./dez. 2016 
amplitude e qualidade, variou de país para país, segundo as suas características históricas, ideológicas e socioeconômicas. Especificamente destaca José Luís Fiori que:

A principal conclusão que se pode extrair deste tema entre os autores que defendem a especificidade estrutural das relações entre Estado, mercado e política na configuração histórica do welfare state é de que não existe nem uma progressão linear nem uma convergência inevitável entre os seus vários tipos nacionais, ou mesmo entre os seus vários padrões de construção e organização do Estado de Bem-Estar Social. O interessante de notar, entretanto, é que respeitadas as individualidades, quase todos os países, tipos e padrões seguiram uma evolução cujos grandes momentos e períodos são análogos porque estão determinados pela trajetória crítica do contexto mais amplo econômico e político-ideológico de que já falamos em que se ambientou o welfare. Mas mesmo quando esta evolução obedece a uma cronologia análoga, suas características e conseqüências têm sido diferentes em cada país, dependendo, é óbvio, das regras e formas que se consolidaram previamente. ${ }^{13}$

Tal remodelamento acolhido pelo sistema capitalista é explicado pelos autores franceses Boltanski e Chiapello ${ }^{14}$, em boa medida, como uma resposta ao que eles denominam de crítica (voice), que tem papel fundamental como agente de mudança do capitalismo (embora não seja o seu principal). Essa crítica se materializa no protesto público, no direito de indignação e de denunciar publicamente (formato inerente à modernidade e à democracia) violações que são atentatórias às possibilidades de realização da humanidade dos seres, o que, aliado a um trabalho de reflexão dos responsáveis empresariais e seus assistentes, visando reproduzir sucessos e compreender fracassos, estabelece uma espécie de cartografia do mundo em certo estado do capitalismo, que se desloca e se reinventa, adaptando-se, mas com o mesmo espírito que mantém o engajamento das pessoas no processo de criação do lucro.

Contudo, não se olvidando que esse formato exigiu uma nova repactuação de repartição das riquezas (a que cedeu o capitalismo, ante as já citadas circunstâncias históricas), não tardou a aparecer a reação capitalista, que veio nos anos 60/70 quando se começou a questionar acerca da onerosidade dos Estados para manter essa política de bem-estar social, ideologia que surgiu para solapar as conquistas sociais, mediante o debate e movimento dos conservadores sobre a chamada crise de governabilidade.

Vale no ponto registrar o informe publicado pela Organização para a Cooperação e Desenvolvimento Económico ou Econômico (OCDE), intitulado "The Welfare State in Crisis", de 1981 (Conference on Social Policies in the 1980s, OECD, Paris, 20-23 October 1981), noticiado por José Luís Fiori ${ }^{15}$, no qual significativo foi o diagnóstico no sentido de que a rápida e continuada expansão dos programas sociais em 1950 e 1960, que esteve estreitamente relacionada às altas taxas de crescimento econômico, teve de ser revisto, no início de 1970, em razão do desempenho mais fraco da economia, levando à crise financeira da segurança social, considerando as altas taxas de desemprego de então, impactando nos gastos sociais e com efeitos negativos sobre a economia, a inibir a retomada do crescimento não-inflacionista.

13 FIORI, José Luís. Estado de bem-estar social: padrões e crises. Physis, Rio de Janeiro, v. 7, n. 2, p. 129-147, Dez. 1997. Disponível em: <http://www.scielo.br/scielo.php?script=sci_arttext\&pid=S010373311997000200008\&lng=en\&nrm=iso>. Acesso em 28 jun. 2016. http://dx.doi.org/10.1590/S010373311997000200008.

14 BOLTANSKI, Luc; CHIAPELLO, Ève. O novo espírito do capitalismo. São Paulo: Martins Fontes, 2009, p. 486487. Tradução: Ivone C. Benedetti

15 FIORI, José Luís. Estado de bem-estar social: padrões e crises. Physis, Rio de Janeiro, v. 7, n. 2, p. 129-147, Dez. 1997. Disponível em: <http://www.scielo.br/scielo.php?script=sci_arttext\&pid=S010373311997000200008\&lng=en\&nrm=iso>. Acesso em 28 jun. 2016. http://dx.doi.org/10.1590/S010373311997000200008. 
Todavia, a ideologia do neoliberalismo, conforme relata Perry Anderson ${ }^{16}$, surgira, no plano teórico bem antes, isto é, logo depois da II Guerra Mundial, com o livro escrito pelo austríaco Friedrich Hayek, "O Caminho da Servidão" (primeira publicação em 1944), num ataque apaixonado contra qualquer limitação dos mecanismos de mercado por parte do Estado, mirando especificamente à época o Partido Trabalhista inglês, com uma mensagem drástica defendendo que, apesar das boas intenções, a social democracia inglesa levaria ao mesmo resultado desastroso do nazismo alemão, o que intitulou de uma servidão moderna. Hayek combatia o keynesianismo e o solidarismo, defendia a instituição de novas bases para o capitalismo, duro e livre de regras, alertando para os perigos de qualquer regulação do mercado por parte do Estado, pois a política de bem estar social destruía a liberdade dos cidadãos e a vitalidade da concorrência, da qual dependia a prosperidade de todos, vislumbrando ele ainda perigos no que identificou como poder excessivo e nefasto dos sindicatos e do movimento operário, defendendo assim a contenção de gastos com bem-estar, a restauração da taxa "natural" de desemprego (o exército de reserva identificado por Karl Marx), a redução dos impostos sobre rendimentos mais altos e rendas, o que propiciaria o restabelecimento de uma saudável desiguldade que, por sua vez, dinamizaria as economias avançadas.

Poder-se-ia conjecturar que o coroamento do neoliberalismo se dá no plano simbólico, no final de 1970 e durante a próxima década, com o governo de Margaret Thacher, na Inglaterra, e com o governo do Presidente Ronald Regan, nos Estados Unidos, já que no plano concreto a implantação efetivou-se através de uma lenta transição, com implantação gradativa de reformas neoliberais, de ajustes macroeconômicos, que propiciaram a desmontagem do(s) Estado(s) de bem-estar social (welfare state) e minaram a força dos sindicatos, com a volta da mercantilização da força de trabalho, a desregulação dos mercados de trabalho e a privatização de muitos serviços sociais.

Entretanto, tomando de empréstimo a máxima de Millôr Fernandes, segundo a qual, se você não tem dúvidas, é porque está mal-informado ${ }^{17}$, a tudo é preciso estar atento (com foco no espírito do capitalismo) donde cabe indagar se, de fato e profundamente, existiria mesmo uma diferença ideológica entre Keynes e Haeyk, considerando a intrigante provocação e observação de José Luís Fiori, na entrevista que concedeu à repórter Cláudia Antunes, da Folha de S. Paulo, em maio de 2009:

É verdade que as teorias de origem neoclássica e as políticas ortodoxas saíram do primeiro plano. Mas elas permanecem atuantes em todos as frentes de resistência às políticas em curso. Além disso, as novas políticas não significam a morte da ideologia econômica liberal porque, ao contrário do que pensa o senso comum, o keynesianismo também é liberal.

Keynes era um liberal, e sua teoria recupera algumas teses essenciais do ultraliberalismo econômico dos fisiocratas do século 18 e do próprio liberalismo de Adam Smith. Os fisiocratas franceses consideravam indispensável um "tirano esclarecido" para o bom funcionamento das sociedades de mercado. E o próprio Smith defendia a necessidade do Estado para assegurar o funcionamento da sua mão invisível, sempre que fosse necessário proteger os capitais nacionais ou realizar investimentos de infraestrutura que não fossem cobertos pelo capital privado.

Talvez por isso os trabalhistas e os social-democratas europeus tenham trocado com tanta naturalidade as teses keynesianas pelas politicas neoliberais na década de 70, assim como estão se convertendo de novo ao ideário keynesiano.

16 ANDERSON, Perry. Balanço do neoliberalismo. In: SADER, E. e GENTILI, P. Pós-neoliberalismo: as políticas sociais e o estado democrático. Rio de Janeiro: Paz e Terra, 1995, p.9-11.

17 CORTEllA, Mário Sérgio. Dúvida. In: CORTELlA, Mário Sérgio. Pensar bem nos faz bem!: 1. filosofia, religião, ciência e educação. Petrópolis: Vozes, 2013, p.55.

Revista de Direito Brasileira | São Paulo, SP | v. 15 | n. 6 | p. 94- 115 | set./dez. 2016 
Do meu ponto de vista, os neoclássicos e os keynesianos pertencem à mesma família ideológica liberal, e, em política econômica, defendem estratégias que podem ser complementares e que muito provavelmente são indissociáveis dentro do capitalismo. Na verdade, são retóricas e políticas econômicas que atendem a interesses e a funções diferentes, mas intercambiáveis, dependendo do tempo e do lugar. ${ }^{18}$

\section{AS MAIS RECENTES CRISES GERADAS PELO CAPITALISMO E TAMBÉM A PARTIR DELE}

É fato que o movimento neoliberal, de desregulação da economia, teve sua influência maior, de forma radical, no capitalismo financeiro, que redundou na crise bancária, de amplitude global, de 2008 e 2009, gerando um colapso dos mercados imobiliário e de ações, levando aos governos um plano de resgate bilionário para socorrer empresas do setor financeiro (notadamente nos EUA e Europa), citando por mais significativo, a seguradora AIG e as companhias hipotecárias Freddie Mac e Fannie Mae.

Crise essa que provocou a mais profunda recessão nos Estados Unidos, ao menos após a Segunda Guerra Mundial, com taxas de desemprego superando os $10 \%$ da força de trabalho, além do abalo nas finanças do governo, com o deficit público ultrapassando o montante de $10 \%$ do PIB, tendo se constatado que essas vultosas perdas socioeconômicas foram consequência de negócios que se realizavam à margem da vigilância regulatória do mercado financeiro, da fiscalização dos órgãos competentes, e que estavam consubstanciados em empréstimos fraudulentos para compradores de imóveis com baixíssima capacidade de honrar tais compromissos. Os fatos, mais a miúde, os atores responsáveis, a impressionante captura do Estado pelos lobbies e interesses do mercado financeiro, selvagem e inescrupuloso, marcado pela corrupção, estão retratados no documentário Trabalho Interno (Inside Job), de 2010, dirigido por Charles H. Ferguson, exibido no Festival de Cannes de 2010, que ganhou o Oscar de melhor documentário de 2011.

Essa falha de regulação no sistema financeiro propiciou, aliás, o agigantamento de agentes desse mercado, que ficou extremamente oligopolizado, num ambiente propício à fraude em razão da busca do ganho fácil, sem a observância de mínimos patamares éticos, o que se consubstancia na origem do que os americanos definem como "Too big to fail" (tão grande para quebrar ou para falir) ${ }^{19}$, referindo-se, normalmente a instituições ou grandes corporações, do ramo financeiro, que por deterem forte participação no mercado, acarretariam um dano sistêmico, em caso de falência ou concordata, gerando graves danos na economia, nas reservas do país, nos níveis de emprego e renda etc.

O volume de recursos que os governos destinaram para impedir este "risco sistêmico" e manter o sistema financeiro de pé, foram impressionantes. Os Estados Unidos US\$ 700 bilhões, a Alemanha US\$ 683 bilhões, a França US\$ 500 bilhões e a Espanha US\$ 143 bilhões ${ }^{20}$.

A notícia ${ }^{21}$ de que Inspetores Federais da Bolsa de Nova York durante a crise passavam o tempo navegando na internet em sites pornô, conforme investigação feita pela entidade interna

18 ANTUNES. Claudia. "Não há vitória do keynesianismo nem abandono da ideologia liberal", diz Fiori. 03.05.2009. Entrevista. Folha de S. Paulo. Edição On line. Disponível em: <<http://www1.folha.uol.com.br/folha/mundo/ult94u559190.shtml> Acesso em 29 jun. 2016

19 SORKIN, Andrew Ross. Realities Behind Prosecuting Big Banks: Are banks too big to jail?. The New York Times. New York. 11 mar. 2013. Disponível em: <http://dealbook.nytimes.com/2013/03/11/big-banks-gowrong-butpay-a-little-price/?_r=0>. Acesso em: 04 abr. 2015

20 BBC. Versão On line. Cronologia da crise. 02.09.2009. Disponível em <http://www.bbc.com/portuguese/noticias/2009/09/090902_aftershock_timeline_noflash.shtml> Acesso em 30 jun. 2016 
encarregada de controlar a SEC - Securities and Exchange Commission (o equivalente à nossa Comissão de Valores Mobiliários), foi demasiadamente negativa. Embora tendo constatado que apenas 31 dos 3500 inspetores assim agiam, identificou que 17 desses consumidores de pornografia nos escritórios públicos eram altos funcionários do organismo, com salários de até 200.000 dólares anuais.

Ante tal quadro é interessante constatar a contradição destacada pela visão aguda de Eros $\mathrm{Grau}^{22}$, quando afirma que realisticamente o mercado se move por interesses egoísticos, buscando o maior lucro possível, colocando o direito a seu serviço, reclamando a atuação estatal para propiciar e assegurar a fluência de suas relações, porém, contraditoriamente, exorciza tal intervenção do Estado, postulando seja ela mínima, sendo certo contudo que a fluência das relações mercadológicas não poderiam subsistir sem o direito positivo, o direito posto pelo Estado, mas que surge também para disciplinar o mercado e domesticar os determinismos econômicos.

Vale a esta altura trazer o olhar crítico e de alerta de Laura Carvalho, sobre esse panorama que volta a se apresentar na atualidade:

O livro "A Nova Razão do Mundo", dos franceses Christian Laval e Pierre Dardot, recém-lançado pela Boitempo, nos ajuda a entender o fenômeno. O neoliberalismo não seria uma doutrina econômica, e sim um instrumento de desativação do jogo democrático. Já dizia Margaret Thatcher - referência da presidente interina do BNDES: "A economia é o método. O objetivo é mudar a alma".

A teoria econômica vem se mostrando bem-sucedida em evitar as consequências de uma radicalização da democracia pela conquista de direitos e cidadania. A solução, sob o véu da técnica, é criar outra forma de sujeição. A liberdade menor é travestida de liberdade maior. Vende-se a ideia de que a falta de liberdade deriva da submissão a um sujeito para o qual a sociedade não deve nada: o Estado. Uma doutrina que promete a liberdade de escolha, mas é vendida sempre sob o slogan da falta de alternativas.

E aquele Estado, potencial garantidor das demandas dessa mesma sociedade por mais proteção social, melhores serviços e maior igualdade de tratamento, tornase um inimigo. Não só no discurso mas também na prática, pois a tal doutrina econômica encarrega-se de mantê-lo sob o controle das oligarquias.

Friedrich Hayek, em sua visita ao Chile de Pinochet, não hesitou em deixar clara a sua preferência por "uma ditadura liberal, em vez de um governo democrático desprovido de liberalismo". Hayek, aliás, esteve presente -com Ludwig Von Mises- na reunião de 1938 em Paris que cunhou o termo "neoliberalismo", em uma reação ao que ambos enxergavam como uma ameaça quase tão perigosa quanto o nazismo e o comunismo: o surgimento da social-democracia, aquela do New Deal de Roosevelt e do incipiente Estado de Bem-Estar Social britânico.

Mas foi nas crises que a agenda ganhou mais terreno. Afinal, seus teóricos costumam aproveitar-se da distração da população para impor políticas impopulares, como documentou Naomi Klein em seu livro "A Doutrina do Choque". Tendo aprendido bem com o golpe chileno, Milton Friedman chega a descrever o furacão Katrina como uma "oportunidade para reformar

21 AFP. Agence France-Presse. Inspetores da bolsa de Nova York assistiram a pornografia durante a crise. Portal G1. 23.04.2010. Disponível em: <http://g1.globo.com/economia-e-negocios/noticia/2010/04/inspetores-da-bolsa-denova-york-assistiram-a-pornografia-durante-a-crise.html > - Acesso em 29 jun. 2016.

22 GRAU, Eros. A Ordem Econômica na Constituição de 1988. 11 a ed. São Paulo: Malheiros, 2006, p. 30-32 e 3637

Revista de Direito Brasileira | São Paulo, SP | v. 15 | n. 6 | p. 94- 115 | set./dez. 2016 
radicalmente o sistema educacional de Nova Orleans". A maior parte do sistema de ensino público da cidade foi privatizada em 19 meses. $^{23}$

Aprofundando mais essa análise, em entrevista que concedeu à repórter Elizabeth Carvalho, no programa Milênio exibido pelo canal de TV por assinatura GloboNews, no dia 27.06.2016 ${ }^{24}$, o jurista francês Alain Supiot (Diretor do Instituto de Estudos Avançados da Universidade de Nantes, na França), destacou que o capitalismo se constrói sobre a ideia de que podemos tratar três itens essenciais como mercadorias, mas que não são: trabalho, terra e moeda, o que de resto já havia sido constatado, segundo ele, por Karl Polanyi. Por isso Supiot realça que se esses três itens que não são produtos, mas condições de produção, forem tratados como mercadorias, destruiremos própria condição de produção, como por exemplo o meio ambiente, do qual depende uma economia saudável.

No mais, defende ainda Alain Supiot que os direitos trabalhistas surgiram para tornar suportável, possível e duradoura, a exploração do trabalho humano como um produto comercializável, daí porque se outorgou ao trabalhador proteções que garantam o tempo longo na vida de trabalho dele, face às exigências do tempo curto de mercado. Essas são construções feitas num Estado que é chamado de social, num sentido maior, que se aplicam de forma diferente de país para país. Mas esse contexto mudou dentro do que chamamos de globalização, que incentiva a concorrência entre trabalhadores do mundo todo, um contra os outros, num contexto atual de destruição das fronteiras nacionais. E todos os países do mundo são incentivados a destruir essa proteção nacional em nome do que, em economia, denominamos vantagem comparativa, expressão tomada de empréstimo do economista David Ricardo (um dos fundadores da escola clássica inglesa da economia política), que via o mundo como um grande supermercado, no qual cada país devia cultivar sua vantagem comparativa. Assim todos os países do mundo estão engajados na luta pela diminuição do uso do estatuto do trabalho, de leis trabalhistas protetivas. As palavras de ordem são principalmente as que anunciam medidas de destruição dessas proteções, que foram herdadas do período da revolução industrial.

Não é por outro motivo que o professor de Ciência Política na Universidade Complutense de Madrid, Juan Carlos Mondenero ${ }^{25}$, em artigo intitulado "Posdemocracia? Frente al pesimismo de la nostalgia, el optimismo de la desobediencia", traça uma visão apontando que estamos diante de um esvaziamento dos processos democráticos, com o surgimento de novas formas de articulação política, sendo certo que a impotência não só da União Europeia, mas também o G-7, o G-8 ou G-20 mostra que o que está em jogo é o pacto social que realizou o Estado social e democrático de direito, indicando um futuro incerto, o que nos impõem um olhar atento e o acompanhamento do desenrolar de tal panorama.

Considerados tais diagnósticos, talvez se possa afirmar que as reações de base começam a se mostrar, como por exemplo na França que encontra-se hoje mergulhada numa onda de greves que já dura cerca de três meses (notícia com pouco espaço na mídia), contra as reformas

23 CARVALHO, Laura. Bela, recatada e do lar. Folha de S. Paulo. São Paulo, 16 jun. 2016. Caderno Mercado, p. A22

24 CARVALHO, Elizabeth. Jurista francês Alain Supiot fala sobre Europa, UE e trabalho. Programa Milênio. Entrevista. GloboNews. 27.06.2016. Disponível para assinantes em: <http://g1.globo.com/globonews/milenio/videos/t/milenio/v/milenio-jurista-frances-alain-supiot-fala-sobre-europa-ue-e-trabalho/5124303/>

Acesso em 29 jun. 2016

25 MONDENERO, Juan Carlos. Posdemocracia? Frente al pesimismo de la nostalgia, el optimismo de la desobediencia. publicado na revista Nueva Sociedad no 240, julho-agosto de 2012, ISSN: 0251-3552. Disponível em: <http://nuso.org/articulo/posdemocracia-frente-al-pesimismo-de-la-nostalgia-el-optimismo-de-la-desobediencia/> Acesso em 29 jun. 2016. 
trabalhistas que se pretende implementar naquele país, levando o seu primeiro primeiro-ministro, Manuel Valls, a admitir a possibilidade de mudanças ou melhorias na proposta ${ }^{26}$.

Isso ao mesmo tempo em que os ingleses votaram pela saída da Grã-Bretanha da Comunidade Europeia (Brexit: Britain exit) que, para além de um resultado de referendo sobre maior liberdade comercial e imigração entre países, aponta para um início de reação ao poder das entidades políticas globalistas (leia-se aqui: Parlamento Europeu e Comissão Europeia), quanto à imposição de políticas que se afastaram do compromisso de propiciar bem-estar aos cidadãos e focaram num cientificismo contemporâneo que pressupõe um mundo sem leis e governado pelos números, regido pelos cálculos de utilidades, pela administração das coisas, da gestão das relações, fundada em cálculos utilitários.

Útil para a compreensão das consequências dessa erosão do welfare state, com o solapamento da proteção social é a observação do pensador parisiense Régis Debray ${ }^{27}$, quanto à postura xenófoba em relação aos refugiados que migram para o continente europeu, anotando que é o problema mais grave do século 21, o que deixa a esquerda diante de inusitada contradição, ante a constatação de que as camadas mais pobres nos países da Europa são justamente as mais alérgicas à entrada de imigrantes, porque estes arruínam suas chances de emprego e mudam seu modo de vida, residindo nessa realidade os motivos pelos quais os ricos não se importam tanto, já que os imigrantes (no caso da França) não se instalarão na "Place de la Concorde", pois irão para as banlieues (os subúrbios carentes, a periferia), o que o leva a vaticinar que o mundo sem fronteiras é um pesadelo, não um sonho.

Essa visão aliás é também a que adota Bresser-Pereira em artigo publicado no jornal Folha de S. Paulo, sob o título "A indignação do povo", no qual anota que:

Em meio a uma crise profunda, nós brasileiros nos sentimos muito mal. Mas com a saída do Reino Unido da União Europeia, o mundo rico, liberal e global está se sentindo igualmente muito mal, derrotado como nós nos sentimos derrotados.

A saída dos britânicos da União Europeia é um fenômeno político com a mesma origem do grande crescimento dos partidos e candidatos de extrema-direita na Europa e nos Estados Unidos. Ele se deve ao apoio crescente que os trabalhadores e os pobres vêm dando a esses partidos.

Dessa maneira, esses setores manifestam seus protestos contra um sistema político no qual a ideia de nação e a solidariedade que a acompanha foram abandonadas. Contestam um liberalismo econômico radical que ignora os interesses das pessoas e seus direitos. ${ }^{28}$

\section{CAPITALISMO, SUAS CRISES E A CONSTITUIÇÃO BRASILEIRA}

Sob o background do que até aqui exposto, voltemos agora nossos olhos ao cenário brasileiro, visto inicialmente a partir do jogo das forças que moldaram a nossa Constituição republicana, que foi apreendido com perspicácia por Oscar Vilhena, no termo que cunhou como "resiliência textual". Resiliência entendida, consoante ele mesmo explica, utilizando uma

26 AFP. Agence France-Presse. Trabalhadores de usinas nucleares aderem à onda de greves na França. Folha de S. Paulo. Edição On line. 26.05.2016. Disponível em: <http://wwwl.folha.uol.com.br/mundo/2016/05/1775264trabalhadores-de-usinas-nucleares-aderem-a-onda-de-greves-na-franca.shtml> Acesso em 29. jun. 2016

27 AQUINO, Ruth. Régis Debray: “A esquerda está sem voz”: O filósofo francês, companheiro de guerrilha de Che Guevara, elogia o "revoltado" papa Francisco e diz que o islamismo é a única oposição séria ao capitalismo. 24.08.2015. Revista Época. Edição On line. Disponível em: < http://epoca.globo.com/ideias/noticia/2015/08/regisdebray-esquerda-esta-sem-voz.html> - Acesso em 28 jun. 2016.

28 BRESSER-PEREIRA, Luiz Carlos. A indignação do povo. Folha de S. Paulo. São Paulo, 30 jun. 2016. Caderno Opinião. Tendências/Debates, p. A-3 
definição emprestada de um conceito da física, como a propriedade que possui alguns materiais de acúmulo de energia, quando exigidos ou submetidos a estresse, sem que ocorra ruptura ou modificação permanente, perdurando no tempo e retornando ao ponto de equilíbrio, de modo que, sob essa perspectiva, divisa esse jurista, dentre outras características de nossa Carta constitucional, as seguintes:

A Constituição de 1988 é ideológica e retoricamente carregada. Isso não significa, no entanto, que tenha assumido uma clara diretriz política ou mesmo econômica. A fragmentação político-partidária, a multiplicidade de grupos de interesses presentes no processo constituinte e a intensa participação da sociedade geraram uma constituição que abrigou interesses distintos ou mesmo contrapostos. Sua marca distintiva, portanto, não é o caráter desenvolvimentista, liberal, "chapa-branca", neoconstitucional, simbólico ou ubíquo, mas sim o compromisso maximizador, que garantiu que todos os setores que foram capazes de se articular no processo constituinte tivessem satisfeita ao menos parcela de seus interesses. A Constituição entrincheirou direitos, protegeu interesses, distribuiu poderes, realizou promessas, delineou objetivos de mudança social e determinou políticas públicas

[...] não foi um pacto social entre iguais, mas também não pode ser confundida com uma simples carta de fachada ou simbólica, voltada a encobrir um rústico modelo de dominação. Temos um pacto assimétrico. Isso gerou um documento igualmente assimétrico no reconhecimento de direitos, na proteção de interesses e mesmo na preservação de esferas de poder. A constituição estabelece direitos que devem ser respeitados, esferas de participação a serem preenchidas e metas que devem ser alcançadas. Prevê também mecanismos orçamentários que buscam assegurar a eficácia de algumas de suas promessas. Essas previsões que fazem a Constituição contraditória permitem que vários setores da sociedade exerçam pressão, juridicamente justificada, para concretizá-las.

$[\ldots]$

A resiliência textual, associada ao consensualismo político, por sua vez, tem contribuído para que o processo político possa constantemente atualizar um texto extensamente ambicioso, mas razoavelmente fácil de ser reformado. Essa resiliência textual, no entanto, não autorizou que elementos centrais de nossa arquitetura constitucional fossem alterados. Por fim, o ambicioso projeto constitucional convocou o Judiciário para servir como elemento de calibração da política, passando a Suprema Corte a exercer um papel quase moderador na articulação e na mediação da atuação dos demais Poderes. ${ }^{29}$

E, nesse embate ideológico, tracionado pela demanda de proteção social no campo do trabalho e políticas sociais a serem mantidas ou implementadas pelo Estado, em contraponto aos interesses do mercado e dos capitalistas que aspiram por menos regulamentação e que estão vivamente interessados em reduzir o seu contributo para que o Estado possa levar avante a redistribuição dos recursos, visando o estabelecimento de mais justiça social, é de se notar que no Brasil, em razão da crise econômica (mais uma) pela qual passa o país (sem falar na política), já é possível identificar as ideias liberalizantes sendo compradas e defendidas pelos atuais dirigentes governamentais, representantes do povo. Vejamos:

O ministro da Casa Civil, Eliseu Padilha, foi aplaudido por empresários e executivos nesta quinta-feira (16) em evento em São Paulo ao falar sobre terceirização do trabalho em uma eventual reforma trabalhista.

29 VILHENA, Oscar. Do compromisso maximizador ao constitucionalismo resiliente. in VILHENA, Oscar et all. Resiliência constitucional: compromisso maximizador, consensualismo político e desenvolvimento gradual, São Paulo: Direito GV, 2013, p. 18-19, 23 
Padilha afirmou que a reforma trabalhista tem que vir junto da Previdência, ou logo depois, e que é preciso fomentar o aumento da produtividade com a formação das pessoas, o que implica a revisão do ensino.

Ambas as reformas, conforme o ministro, estão 'no horizonte deste ano'.

Ele agradou a plateia de representantes do setor privado ao afirmar que o país precisa modernizar o processo produtivo, além de formalizar o emprego e 'caminhar no rumo da terceirização.'

'Temos que caminhar no rumo da terceirização. Aquele projeto que está no Senado deve ser votado com alguma rapidez. ${ }^{30}$

O Plenário aprovou nesta quarta-feira (13), em primeiro turno, substitutivo à Proposta de Emenda à Constituição (PEC) 143/2015, que permite aos estados, Distrito Federal e municípios aplicar em outras despesas parte dos recursos hoje atrelados a áreas específicas, como saúde, educação, tecnologia e pesquisa, entre outras. A PEC ainda será votada em segundo turno.

O substitutivo foi apresentado pelo senador Romero Jucá (PMDB-RR) ...

$[\ldots]$

O texto original da PEC previa a desvinculação para os entes federativos até 2023. Porém, como forma de acelerar a votação da matéria, Jucá acatou sugestão do PSB para que a desvinculação vigorasse em quatro anos, a partir da promulgação da Emenda. As vinculações obrigatórias foram criadas a partir da Constituição de 1988 e beneficiam alguns órgãos, fundos ou categorias de despesas.

$[\ldots]$

O líder do governo no Congresso, José Pimentel (PT-CE) manifestou-se favoravelmente à PEC, e ressaltou que a desvinculação representa uma fonte adicional de recursos aos estados e municípios, que passam por severa crise fiscal.

Jucá garantiu aos colegas que a proposta não prejudica a educação. Segundo ele, a PEC vai "desengessar" e evitar distorção de gastos, ao obrigar investimentos em educação por parte de municípios que perderam população e, na verdade, precisam investir em saúde. ${ }^{31}$

A par do compromisso com ideologia neoliberal, do Estado mínimo, tais movimentos devem gerar indignação, considerado o quanto ainda temos a caminhar para o desenvolvimento socioeconômico e de melhoria da qualidade de vida do povo brasileiro, tendo como panorama os dados do $\mathrm{IBGE}^{32}$ reveladores de que enquanto em 2001, os $20 \%$ mais ricos percebiam uma renda cerca de 24 vezes superior àquela auferida pelos $20 \%$ mais pobres. E, se é certo que essa razão, em 2011, atingiu 16,5 vezes, é preciso destacar que a evolução, todavia, ainda não foi capaz de alterar substancialmente o quadro de desigualdade brasileira na apropriação do rendimento total, uma vez que os $20 \%$ mais ricos ainda detêm $57,7 \%$ desse rendimento, em contrapartida ao pouco mais de $11 \%$ detidos pelos $40 \%$ mais pobres.

É preciso não olvidar ademais que o problema do Brasil é menos de caixa, de arrecadação, e mais de melhoria da qualidade de gestão na implementação de políticas públicas, bem como da condução mais diligente e eficaz da política econômica, considerado o que se

30 CUNHA, Joana. Ministro defende terceirização do trabalho e é aplaudido por executivos. Folha de S. Paulo. São Paulo, 17 out. 2011. Caderno Mercado, p. A-19

31 AGÊNCIA SENADO. Desvinculação de $25 \%$ da receita de estados e municípios é aprovada em primeiro turno. 13.04.2016. Disponível em: <http://www12.senado.leg.br/noticias/materias/2016/04/13/desvinculacao-de-25-dareceita-de-estados-e-municipios-e-aprovada-em-primeiro-turno> Acesso em 29 jun. 2016

32 IBGE. Instituto Brasileiro de Geografia e Estatística. Síntese de indicadores sociais: uma análise das condições de vida da população brasileira 2012. Disponível em <http://biblioteca.ibge.gov.br/bibliotecacatalogo?view=detalhes\&id=282173> Acesso em 29 jun. 2016 
arrecada de tributos, nos três níveis de governo (federal, estadual e municipal). Isso porque foram mais de 1,7 trilhões de reais em 2013, assim como mais de 1,8 trilhões de reais em 2014, segundo os dados oficiais ${ }^{33}$. Para qual parcela dos cidadãos está sendo destinada a maior parte desse volume arrecadado, é o que se tem de sindicar, antes de se movimentar no sentido de deliberar pela desvinculação obrigatória de recursos para áreas sensíveis como saúde e educação, num país no qual as promessas de justiça social ainda estão longe de se tornar realidade. Aliás, no tocante à educação a realidade nos indica o quanto ainda temos que caminhar:

Dois anos após o Plano Nacional de Educação (PNE) entrar em vigor, em junho de 2014, o acompanhamento das metas estabelecidas frustra educadores, que contavam com a força da lei para ver melhorias no ensino do país. Considerado a espinha dorsal para o desenvolvimento educacional no Brasil, o PNE trouxe 20 metas - com uma série de objetivos - a serem atingidas ao longo de dez anos. Mas especialistas e autoridades já perderam as esperanças de ver alcançados os objetivos traçados para 2016, como a universalização das matrículas para crianças de 4 e 5 anos.

$[\ldots]$

Entre as 20 grandes metas do PNE, sete deveriam ter sido alcançadas dois anos após a criação do plano. Segundo o TPE, seis delas não foram atingidas. A lei determinava, por exemplo, que todas as crianças de 4 a 5 anos do país estivessem em salas de aula até este mês. No entanto, há 640 mil crianças, ou $10,9 \%$ da população nessa faixa etária, fora da escola. Os dados mais atualizados são referentes a 2014, mas o monitoramento dos indicadores feito por diferentes ONGs e pelo próprio Ministério da Educação (MEC) informa que a meta não será atingida. ${ }^{34}$

Essas constatações, aliás, nos devem fazer relembrar o que consta no preâmbulo de nossa Constituição cidadã de 1988, quando lá se aponta que o desiderato a partir de então era, e é, a instituição no Brasil de um Estado Democrático, destinado a assegurar o exercício dos direitos sociais e individuais, a liberdade, a segurança, o bem-estar, o desenvolvimento, a igualdade e a justiça como valores supremos de uma sociedade fraterna, pluralista e sem preconceitos, fundada na harmonia social e comprometida, na ordem interna e internacional, com a solução pacífica das controvérsias.

E como princípios fundamentais desse Estado Democrático de Direito, adotou-se, dentre outros, o da cidadania, o da dignidade da pessoa humana, os valores sociais do trabalho e da livre iniciativa, além do pluralismo político, sob a perspectiva de uma democracia representativa, com todo o poder emanado do povo e exercido ordinariamente por meio de representantes eleitos ou, até mesmo diretamente, quando assim se estipular (referendo, plebiscito, iniciativa popular de leis e ação popular).

Toda essa carga de valor já é muito significativa a impor grave e profunda responsabilidade aos nossos representantes eleitos democraticamente. Contudo, há mais, pois como objetivos fundamentais (meta a ser perseguida de forma obstinada pelo Estado brasileiro, pelos governantes e gestores públicos, ou pelo menos que assim deveria ser), estipulou-se o desiderato de construir uma sociedade livre, justa e solidária, acrescido do dever de garantir o desenvolvimento nacional, sem descuidar de erradicar a pobreza e a marginalização, nem de

33 BRASIL. Ministério da Fazenda. Receita Federal. Carga Tributária no Brasil - 2014 (Análise por Tributo e Bases de Incidência). Org. Irailson Calado Santana. Disponível em: http://idg.receita.fazenda.gov.br/dados/receitadata/estudos-e-tributarios-e-aduaneiros/estudos-e-estatisticas/cargatributaria-no-brasil/29-10-2015-carga-tributaria-2014> - Aceso em: 19 jun. 2016

34 FERREIRA, Paula. País não cumpre metas do Plano Nacional da Educação para 2016. Jornal O Globo, Versão on line. 29.06.2016. Disponível em: <http://oglobo.globo.com/sociedade/educacao/pais-nao-cumpre-metas-do-planonacional-da-educacao-para-2016-19604817> Acesso em 29 jun. 2016 
reduzir as desigualdades sociais e regionais, promovendo o bem de todos, sem preconceitos ou quaisquer outras formas de discriminação.

Ademais, esse roteiro traçado como guia para moldar o que se pretende deve ou deva ser o Brasil, é preciso destacar, vem à frente de todos os demais temas regulados na Carta Republicana, pois, reafirme-se, constam desde o preâmbulo e já dos arts. $1^{\circ}$ e $3^{\circ}$, do texto constitucional, à frente e, portanto, com proeminência mesmo sobre os direitos e garantias fundamentais (individuais, coletivos, sociais, de nacionalidade e políticos), previstos nos arts. $5^{\circ}$ a 16.

Ressalte-se ainda, através da verve de Eros Grau ${ }^{35}$, que a Constituição não é um mero instrumento de governo, mas sim um instrumento que enuncia fins, diretrizes e programas a serem realizados pelo Estado e pela sociedade, de modo que para além de um estatuto jurídico, é um plano global-normativo da sociedade, do Estado brasileiro, motivo pelo qual os objetivos e os fins definidos em seus arts. $1^{\mathrm{o}}$ e $3^{\mathrm{o}}$ são os fundamentos e os fins da sociedade brasileira.

E atuação do Estado, sob tal prisma, é imperiosa e decisiva porque, conforme ensinam Boltanski e Chiapelo ${ }^{36}$, no capitalismo é preciso estar atento para o fato de que aqueles que alcançam sucesso (ordinariamente) dispõem de mais bens e recursos do que mereceriam caso o mundo fosse justo, ou, noutro giro verbal, aqueles que fracassam não tiveram realmente, desde o ponto de partida, as mesmas chances de sucesso.

No mais, imperioso desde já vincar, para quem eventualmente tiver dúvidas sobre a força normativa do preâmbulo da Constituição, o que decidiu a Corte Constitucional Francesa (o "Conseil Constitutionnel") sobre o tema, lembrando que a França é conhecida como o berço da democracia:

A emergência do «bloc de constitutionnalité» - Outro fator que contribuiu imensamente para o aprimoramento do sistema foi a decisão proferida pelo Conselho Constitucional em 1971, em um caso envolvendo o direito constitucional de associação.

Até então, o Conselho usava como parâmetro do controle única e exclusivamente os 92 artigos da sintética Constituição promulgada em 1958. Nem mesmo o seu preâmbulo, rico sob o prisma principiológico, era tido como dotado de densidade normativa suficiente para servir de base ao controle de normas. Mas a partir da mencionada decisão de 1971 o controle passou a ser efetuado não mais apenas em face do texto da Constituição, mas tendo como parâmetro o que a doutrina passou a qualificar como «bloc de constitutionnalité», isto é, um catálogo de normas constitucionais e supraconstitucionais composto não apenas pelos 92 artigos da Constituição, mas igualmente pelo seu Preâmbulo, que por sua vez remete diretamente à Declaração Universal dos Direitos do Homem e do Cidadão de 1789 e ao Preâmbulo da Constituição de 1946, fonte de quase todos os direitos sociais fundamentais do país. O Conselho passou também a considerar como integrante do «bloc de constitutionnalité» os «princípios constitucionais reconhecidos pelas leis da República», isto é, todo um catálogo de normas e princípios liberalizantes que o país adotou a partir de 1875 , ou seja, desde quando se desvinculou definitivamente do sistema monárquico. Nos anos 80, incorporou uma nova categoria normativa como norma de referência do controle, os chamados «princípios sociais, políticos e econômicos particularmente necessários ao nosso tempo», os quais permitem uma constante atualização e compatibilização das vetustas concepções de 1789 com as idéias prevalecentes no tempo presente. Portanto, a criação do «bloc» ampliou sensivelmente as possibilidades do

35 GRAU, Eros. A Ordem Econômica na Constituição de 1988. 11ª ed. São Paulo: Malheiros, 2006, p. 364 36 BOLTANSKI, Luc; CHIAPELLO, Ève. O novo espírito do capitalismo. São Paulo: Martins Fontes, 2009, p. 517. Tradução: Ivone C. Benedetti 
controle, na medida em que a obra ordinária do Parlamento passou a ser confrontada com normas supraconstitucionais de ambição e aceitação universais, muitas delas já fazendo parte da consciência político- filosófica de boa parte do mundo. ${ }^{37}$

Por outro lado, é bem verdade, não se pode fechar os olhos para a constatação de que o capitalismo, como regime socioeconômico, com suas bases tradicionais da livre iniciativa, da propriedade privada, da livre concorrência, da legitimação do uso do poder econômico, também encontra guarida no nosso texto constitucional.

Frise-se, o uso do poder econômico está, de fato, estabelecido e tutelado na Constituição, pois no art. 173, $\S 4^{\circ}$, está expresso e explícito que a lei reprimirá o abuso (refirme-se o abuso, e não o uso) do poder econômico que vise à dominação dos mercados, à eliminação da concorrência e ao aumento arbitrário dos lucros. Aliás é de se notar que tal dispositivo endereça a mensagem de que a repressão ao abuso do poder econômico tem como desiderato manter, ao fim e ao cabo, o bom funcionamento, em última análise, do próprio capitalismo, que conquanto seu cunho egoístico, depende certas regras refreadoras incidentes sobre o mercado para sobreviver, como a proteção à liberdade de concorrência, além da ausência de dominação (arbitrária), que acaba por impedir a livre iniciativa e o que se denomina de empreendedorismo.

No entanto, em contraponto a tais aspectos, a nossa Constituição enuncia em seu art. $1^{\circ}$, inciso IV, que estão dentre os fundamentos da República Federativa os valores sociais do trabalho e da livre iniciativa. Cabe assim observar, atentamente, que não somente no que diz respeito ao trabalho, mas igualmente no que tange à livre iniciativa, princípio da economia de mercado, a tutela e o reconhecimento constitucional só tem significado quando considerado o valor social aos quais estão vinculados tais postulados.

Tal raciocínio é reforçado pelo que se encontra no caput do art. 170 da Constituição, de modo a se poder concluir, indene de dúvidas, que a ordem econômica, para além da livre iniciativa, deve estar hipotecada à valorização do trabalho humano, eleito como um vetor constitucionalmente tutelado e, ademais, com o desiderato de garantir a todos uma existência digna, sob a perspectiva da justiça social.

Aliás, lembra-nos Eros Grau ${ }^{38}$, através de seu olhar crítico e agudo que, como princípio, a justiça social está albergada há várias décadas na história de nosso direito constitucional (conquanto, afirme ele, inutilmente), vez que grafada desde a Constituição de 1946 (art. 145), sendo ratificado na Constituição de 1967 (art. 157) e igualmente na emenda constitucional $\mathrm{n}^{\circ}$ 1/69 (art. 160).

Portanto, essa ausência de preocupação ou incapacidade na busca da justiça social, após tantos anos de reconhecimento da necessidade de que a torne uma realidade, não deixa, em certa medida, de ser uma atitude fascista, valendo, no ponto, registrar a reflexão do jornalista, escritor, acadêmico e ambientalista do Reino Unido, George Monbiot, em artigo que escreveu para o site "Outras Palavras", intitulado "Para compreender o neoliberalismo além dos clichês", louvando-se nas ideias do também jornalista estadunidense Chris Hedges, do falecido historiador britânico Tony Judt (que foi professor na Universidade de Nova York), e do filósofo e economista austríaco Friedrich Hayek (autor da controvertida e já aqui citada obra "O Caminho da Servidão"):

Chris Hedges observa que "movimentos fascistas constroem suas bases não entre as pessoas politicamente ativas, mas entre as politicamente inativas, os 'perdedores' que sentem, frequentemente de modo correto, que não têm voz ou

37 GOMES, Joaquim Benedito Barbosa. A quebra de mais um tabu no mundo jurídico: implantação e evolução da jurisdição constitucional na França. Interesse Público, v. 5, n. 19, p. 13-43, maio/jun. 2003

38 GRAU, Eros. Título VIII Da ordem econômica e financeira: Capítulo I Dos princípios gerais da atividade econômica. In: CANOTILHO, J. J. Gomes et al (Org.). Comentários à constituição do Brasil. São Paulo: Saraiva Almedina, 2013. p. 1794. (5 Tiragem 2014)

Revista de Direito Brasileira | São Paulo, SP | v. 15 | n. 6 | p. 94 - 115 | set./dez. 2016 
papel a desempenhar no establishment politico". Quando o debate político não faz mais sentido para nós, as pessoas tornam-se suscetíveis a slogans, símbolos e sensações. Para os admiradores de Trump, por exemplo, fatos e argumentos parecem irrelevantes.

Tony Judt explicou que quando a espessa rede de interações entre as pessoas e o Estado é reduzida a nada, a não ser autoridade e obediência, a única força remanescente a nos unir é o poder estatal. O totalitarismo temido por Hayek tem mais probabilidade de emergir quando os governos, tendo perdido a autoridade moral que emana da garantia de serviços públicos, são reduzidos a "persuadir, ameaçar e em última análise coagir as pessoas a obedecê-los."

Assim, esses valores e normas que constam de nossa Carta Maior é que devem guiar o Estado, os nossos governos, cumprindo observar que esperanças despontam no nosso horizonte, ante a demonstrada capacidade de mobilização e reação popular, retratada nas recentes manifestações que levaram milhões de brasileiros às ruas ${ }^{39}$, para protestar contra o que pode-se identificar como um certo descompromisso dos governantes com o bem-estar de todos, o que tornou imperioso relembrar com a voz das ruas que numa democracia representativa todo poder emana do povo e em seu nome é que deve ser exercido.

Parafraseando o filósofo alemão Ernst Bloch ${ }^{40}$, podemos refletir prospectivamente que temos ainda muito pela frente, mas estamos constantemente à frente, topando com limites que já não são mais limites, pois quando tomamos a consciência deles, os ultrapassamos.

\section{CONCLUSÃO}

Não é só o Estado que está em crise, mas a própria democracia, considerando que a lógica capitalista hegemônica no hodierno mundo globalizado tem conseguido dominar e se impor, através de um cientificismo contemporâneo, fundado em cálculos utilitários, calcado na administração das coisas.

E isto, é mister observar, em prejuízo ou com sacrfícios ao bem-estar social, à busca da justiça social, desiderato manifestado após a Primeira Guerra Mundial, com a constituição da Organização Internacional do Trabalho e reiterada ao final da segunda Guerra Mundial, em Montreal, Canadá, em 1946, por ocasião de sua $29^{a}$ Sessão de Conferência Geral, segundo a qual a paz para ser universal e duradoura deve assentar sobre a justiça social.

As crises (notadamente econômicas) que tanto prejuízos trazem aos cidadãos, impactando profundamente a maioria, que é aquela que está na base da pirâmide injusta e ignóbil da distribuição de riquezas, não é capaze de abalar (ao menos radical e mais profundamente) o sistema capitalista, que com o seu espírito resiliente, explicado pelos franceses Luc Boltanski e Éve Chiapello, e de certa forma pelo alemão Max Weber, convence a todos que é o que tem de melhor para a nossa vida no globo.

O capitalismo tem, indiscutivelmente, a capacidade de absorver as críticas, se remodelar e se reinventar, continuando a obter o engajamento das pessoas, convencendo-as a vender a sua força de trabalho, transformado-a em mercadoria, e ademais não perdendo as suas características fundamentais, de busca insaciável do lucro, de infinita acumulação de riquezas, introjetando a ideia de que é um sistema libertário, quando é da sua essência a geração da desigualdade na

39 PORTAL G1. São Paulo. Manifestantes fazem maior protesto nacional contra o governo Dilma. 13.03.2016. Disponível em: < http://g1.globo.com/politica/noticia/2016/03/manifestacoes-contra-governo-dilma-ocorrem-pelopais.html > Acesso em 29 jun. 2016

40 BLOCH, Ernst. O Princípio Esperança. V1. Trad. Nélio Schneider. EDUERJ: Contraponto. Rio de Janeiro, 2005, p. 243. 
distribuição das riquezas e dos recursos, bem como de um fracasso ou engodo no que tange ao desiderato de liberdade substancial e justiça social.

A dominação e captura desse sistema capitalista, nos dias atuais, baseado no fluxo de capitais financeiros, considerando a moeda como mercadoria e não como condição de produção, tem alcançado proporções alarmantes, anulando a arte de governar, como a atuação do Estado em prol do bem comum, de todos, propiciando um acesso mais democrático aos bens e recursos, trabalhando com o objetivo de capacitar e possibilitar a todos cidadãos o acesso aos benefícios trazidos pelo progresso social, material, tecnológico etc., enfim arbitrando com justiça o conflito redistributivo.

Assim, para além desses aspectos de caráter universal, que afeta a todas as nações, com maior ou menor impacto, no plano interno é preciso ressignificar ou relembrar o significado dos objetivos fundamentais adotados na nossa Constituição republicana, como plano globalnormativo da sociedade, do Estado brasileiro, que não podem ser olvidados, mormente em períodos de crises, quando se faz necessário a intensificação e o aperfeiçoamento das políticas públicas, visando reforçar a proteção social para aqueles que sempre, ao fim e ao cabo, colhem os prejuízos da crise e a sentem de forma muito mais intensa, já que a tarefa de reduzir as desigualdades sociais longe ainda está de ser satisfatoriamente implementada, exigindo tenacidade e compromisso na arte de governar, com e para o povo, pois numa verdadeira democracia é em seu nome que se exerce o poder Estatal.

\section{BIBLIOGRAFIA}

A TRAGÉDIA de Mariana. Estadão. Opinião. Editorial. 11.11.2015. Disponível em: <http://opiniao.estadao.com.br/noticias/geral,a-tragedia-de-mariana,10000001681> Acesso em 29 jun. 2016.

AFP. Agence France-Presse. Inspetores da bolsa de Nova York assistiram a pornografia durante a crise. Portal G1. 23.04.2010. Disponível em: <http://g1.globo.com/economia-enegocios/noticia/2010/04/inspetores-da-bolsa-de-nova-york-assistiram-a-pornografia-durante-acrise.html> - Acesso em 29 jun. 2016.

. Trabalhadores de usinas nucleares aderem à onda de greves na França. Folha de S.

Paulo. Edição On line. 26.05.2016. Disponível em: <http://www1.folha.uol.com.br/mundo/2016/05/1775264-trabalhadores-de-usinas-nuclearesaderem-a-onda-de-greves-na-franca.shtml> Acesso em 29. jun. 2016.

AGÊNCIA SENADO. Desvinculação de $25 \%$ da receita de estados e municípios é aprovada em primeiro turno. 13.04.2016. Disponível em: <http://www12.senado.leg.br/noticias/materias/2016/04/13/desvinculacao-de-25-da-receita-deestados-e-municipios-e-aprovada-em-primeiro-turno> Acesso em 29 jun. 2016.

ANDERSON, Perry. Balanço do neoliberalismo. In: SADER, E. e GENTILI, P. Pósneoliberalismo: as políticas sociais e o estado democrático. Rio de Janeiro: Paz e Terra, 1995.

ANTUNES. Claudia. "Não há vitória do keynesianismo nem abandono da ideologia liberal", diz Fiori. 03.05.2009. Entrevista. Folha de S. Paulo. Edição On line. Disponível em: <<http://www1.folha.uol.com.br/folha/mundo/ult94u559190.shtml> Acesso em 29 jun. 2016.

AQUINO, Ruth. Régis Debray: "A esquerda está sem voz": O filósofo francês, companheiro de guerrilha de Che Guevara, elogia o "revoltado" papa Francisco e diz que o islamismo é a única 
oposição séria ao capitalismo. 24.08.2015. Revista Época. Edição On line. Disponível em: < http://epoca.globo.com/ideias/noticia/2015/08/regis-debray-esquerda-esta-sem-voz.html> Acesso em 28 jun. 2016.

ARAÚJO, Carlos Roberto Vieira. História do pensamento econômico: uma abordagem introdutória. São Paulo: Editora Atlas, 1995.

BBC. Versão On line. Cronologia da crise. 02.09.2009. Disponível em <http://www.bbc.com/portuguese/noticias/2009/09/090902_aftershock_timeline_noflash.shtml> Acesso em 30 jun. 2016.

BLOCH, Ernst. O Princípio Esperança. V1. Trad. Nélio Schneider. EDUERJ: Contraponto. Rio de Janeiro, 2005, p. 243.

BOLTANSKI, Luc; CHIAPELLO, Ève. O novo espírito do capitalismo. São Paulo: Martins Fontes, 2009, Tradução: Ivone C. Benedetti.

BOWEN, Howard R.. Responsabilidades Sociais do Homem de Negócios. Tradução de Octávio Alves Velho. Rio de Janeiro: Civilização Brasileira S/A, 1957,

BRASIL. Ministério da Fazenda. Receita Federal. Carga Tributária no Brasil - 2014 (Análise por Tributo e Bases de Incidência). Org. Irailson Calado Santana. Disponível em: <http://idg.receita.fazenda.gov.br/dados/receitadata/estudos-e-tributarios-e-aduaneiros/estudos-eestatisticas/carga-tributaria-no-brasil/29-10-2015-carga-tributaria-2014> - Acesso em: 19 jun. 2016.

BRESSER-PEREIRA, Luiz Carlos. A indignação do povo. Folha de S. Paulo. São Paulo, 30 jun. 2016. Caderno Opinião. Tendências/Debates, p. A-3

CARVALHO, Elizabeth. Jurista francês Alain Supiot fala sobre Europa, UE e trabalho. Programa Milênio. Entrevista. GloboNews. 27.06.2016. Disponível para assinantes em: <http://g1.globo.com/globo-news/milenio/videos/t/milenio/v/milenio-jurista-frances-alain-supiotfala-sobre-europa-ue-e-trabalho/5124303/> Acesso em 29 jun. 2016.

CARVAlHO, Laura. Bela, recatada e do lar. Folha de S. Paulo. São Paulo, 16 jun. 2016. Caderno Mercado, p. A-22.

CORTELLA, Mário Sérgio. Dúvida. In: CORTELLA, Mário Sérgio. Pensar bem nos faz bem!: 1. filosofia, religião, ciência e educação. Petrópolis: Vozes, 2013.

CUNHA, Joana. Ministro defende terceirização do trabalho e é aplaudido por executivos. Folha de S. Paulo. São Paulo, 17 out. 2011. Caderno Mercado, p. A-19.

FERREIRA, Paula. País não cumpre metas do Plano Nacional da Educação para 2016. Jornal O Globo, Versão on line. 29.06.2016. Disponível em: <http://oglobo.globo.com/sociedade/educacao/pais-nao-cumpre-metas-do-plano-nacional-daeducacao-para-2016-19604817> Acesso em 29 jun. 2016.

FIORI, José Luís. Estado de bem-estar social: padrões e crises. Physis, Rio de Janeiro, v. 7, n. 2, p. 129-147, Dez. 1997.15 Disponível 
<http://www.scielo.br/scielo.php?script=sci_arttext\&pid=S0103-

$73311997000200008 \& \operatorname{lng}=$ en $\& n r m=i s o>\quad$ Acesso $\quad$ em http://dx.doi.org/10.1590/S0103-73311997000200008.

jun.

2016.

GOMES, Joaquim Benedito Barbosa. A quebra de mais um tabu no mundo jurídico: implantação e evolução da jurisdição constitucional na França. Interesse Público, v. 5, n. 19, p. 13-43, maio/jun-2003.

GRAU, Eros. A Ordem Econômica na Constituição de 1988. 11ª ed. São Paulo: Malheiros, 2006.

. Título VIII Da ordem econômica e financeira: Capítulo I Dos princípios gerais da atividade econômica. In: CANOTILHO, J. J. Gomes et al (Org.). Comentários à constituição do Brasil. São Paulo: Saraiva Almedina, 2013 (5ª Tiragem 2014).

HUNT, E. K. História do Pensamento Econômico. Tradução de José Ricardo Brandão Azevedo e Maria José Cyhlar Monteiro. Rio de Janeiro: Campus, 2005.

IBGE. Instituto Brasileiro de Geografia e Estatística. Síntese de indicadores sociais: uma análise das condições de vida da população brasileira 2012. Disponível em <http://biblioteca.ibge.gov.br/biblioteca-catalogo?view=detalhes\&id=282173> Acesso em 29 jun. 2016.

MATOS, Alderi Souza de.O protestantismo norte-americano: séculos 17 a 19. Disponível em: < http://www.mackenzie.br/7111.html> - Acesso em 28 jun. 2016.

MONDENERO, Juan Carlos. Posdemocracia? Frente al pesimismo de la nostalgia, el optimismo de la desobediencia. publicado na revista Nueva Sociedad $n^{\circ} 240$, julho-agosto de 2012, ISSN: 0251-3552. Disponível em: < http://nuso.org/articulo/posdemocracia-frente-al-pesimismo-de-lanostalgia-el-optimismo-de-la-desobediencia/> - Acesso em 29 jun. 2016.

PEREIRA, Jeferson Botelho. Desastre de Mariana/MG e responsabilidade penal da pessoa jurídica. Revista Jus Navigandi, Teresina, ano 20, n. 4518, 14 nov. 2015. Disponível em: <https://jus.com.br/artigos/44355>. Acesso em: 28 jun. 2016.

PORTAL G1. São Paulo. Manifestantes fazem maior protesto nacional contra o governo Dilma. 13.03.2016. Disponível em: < http://g1.globo.com/politica/noticia/2016/03/manifestacoes-contragoverno-dilma-ocorrem-pelo-pais.html> Acesso em 29 jun. 2016.

ROPPO, Enzo. Transformações do contrato na sociedade contemporânea "declínio" ou "relançamento" do instrumento contratual?. In: ROPPO, Enzo. O Contrato. Coimbra: Almedina, 1988. Cap. V.

SORKIN, Andrew Ross. Realities Behind Prosecuting Big Banks: Are banks too big to jail?. The New York Times. New York. 11 mar. 2013. Disponível em: <http://dealbook.nytimes.com/2013/03/11/big-banks-gowrong-but-pay-a-little-price/?_r=0>. Acesso em: 04 abr. 2015.

TOCQUEVILLE, Alexis de. A Democracia na América: Livro II Sentimentos e Opiniões. São Paulo: Martins Fontes, 2004. Tradução: Eduardo Brandão. 
VILHENA, Oscar. Do compromisso maximizador ao constitucionalismo resiliente. in VILHENA, Oscar et all. Resiliência constitucional: compromisso maximizador, consensualismo político e desenvolvimento gradual, São Paulo: Direito GV, 2013.

WEBER, Max. A ética protestante e o espírito do capitalismo. $2^{\mathrm{a}}$ Edição Revista. Editora: Pioneira. 